\title{
Article
}

\section{Study of Thyroid Hormone Status in Ischemic Heart Disease (IHD)}

\author{
Nasreen Sultana Lovely ${ }^{1}$, Rokeya Begum², Qazi Shamima Akhter ${ }^{3}$, Most. Sabinus Sultana ${ }^{4}$, \\ Salina Akhtar ${ }^{5}$
}

\begin{abstract}
Background: Thyroid dysfunction especially hypothyroidism is cardiovascular risk factor because of its association with elevated serum total and LDL cholesterol. Objective: To assess the association of thyroid hormone levels with IHD. Methods: This cross-sectional study was carried out on 50 IHD subjects aged 35 to 85 years (Group B), in the Department of Physiology, Dhaka Medical College, Dhaka from of July 2009 to June 2010. For comparison 50 age, sex, and BMI matched apparently healthy subjects (Group-A) were also studied. The study subjects were selected from coronary care unit (CCU) of Cardiology Department \& OPD of Dhaka Medical College Hospital, Dhaka. Serum FT ${ }_{3}$, $\mathrm{FT}_{4}$ and TSH were assessed by radio-immuno assay. Statistical analysis was done by student's unpaired ' $t$ ' test and chi-square test as applicable. Result: The mean $\pm \mathrm{SD}$ of serum $\mathrm{FT}_{3}$ and $\mathrm{FT}_{4}$ were significantly lower and serum TSH was significantly higher in IHD patients than that of healthy subjects $(\mathrm{p}<0.05)$. Conclusion: Hypothyroidism occurs in patients suffering from IHD.
\end{abstract}

Key words: Thyroid hormone, IHD.

J Bangladesh Soc Physiol. 2011 June; 6(1): 27-31

For author affiliations, see end of text.

http://www.banglajol.info/index.php/JBSP

\section{Introduction}

I schemic heart disease (IHD) or Atherosclerotic coronary artery disease has become global health problem of $21^{\text {st }}$ century because of its high prevalence and concomitant increase in risk of morbidity and premature death. By 2020, it is estimated that it will be the major cause of death in all region of the world. ${ }^{1}$

IHD results from myocardial Ischaemia due to imbalance between the supply and demand of the heart for oxygenated blood. There is also reduced supply of nutrients and inadequate removal of metabolites. ${ }^{2}$

The most common risk factors for IHD include hypercholesterolaemia, hypertension, diabetes mellitus \& smoking. ${ }^{1}$

J Bangladesh Soc Physiol. 2011 June; 6(1): 27-31
Now a days, hypothyroidism has been generally considered as cardiovascular risk factor in majority of studies. ${ }^{3-7}$

Overt hypothyroidism, with its accompanying hypercholesterolemia and hypertension has been found to be associated with cardiovascular disease. Moreover sub-clinical hypothyroidism is a strong indicator of risk for atherosclerosis and myocardial infarction. , $^{6-12}$

The high level of serum TSH is associated with multi vessel disease ${ }^{13}$ and also risk for CHD. ${ }^{7,14-16}$

Either low or high level of thyroid hormone could increase the risk for atheroschlerosis, heart failure and cardiac dysarrhythmias. ${ }^{17,18}$ 
Article

Many researcher reported that hypothyroidism is closely associated with IHD. Several studies have investigated the role of thyroid dysfunction IHD. ${ }^{5,19}$ In Bangladesh, the number of patients with IHD are increasing day by day. Again, a large number of people in our country may be found with thyroid dysfunction.

Therefore, this study was carried out to assess the thyroid hormone status in patients with IHD. The findings of this study would contribute to the knowledge regarding the association between thyroid hormone status and ischemic heart disease.

\section{Methods}

This cross sectional study was carried out in the Department of Physiology, Dhaka Medical College, Dhaka from July 2009 to June 2010. Departmental ethical committee approved the protocol. Total number of 100 subjects age ranged 35 to 85 years of both sexes were selected. Fifty apparently healthy subjects were taken as control (Group-A) and 50 diagnosed and documented IHD patients were selected as study group (Group-B). The study group was selected from coronary care unit of cardiology department and OPD of Dhaka Medical College Hospital, Dhaka and control subjects were selected from Dhaka city by personal communication. Subjects with history of thyroid disease, chest pain for other causes or pregnancy were excluded. All ethical consideration for the subjects was taken into account before inclusion into the study. The aims and benefits of the study were explained to each subject and informed consent was taken. A detail history regarding medical, personal, family and socio-economic history was recorded in a preformed questionnaire. With all aseptic preparation $5, \mathrm{ml}$ of venous blood was drawn and serum were prepared. Serum $\mathrm{FT}_{3}, \mathrm{FT}_{4}$ and TSH of all subjects were measured by radio immunoassay at the laboratory for Nuclear Medicine and Ultrasound, Bangladesh Atomic Energy Commission, Dhaka Medical College Campus, Dhaka. Data were expressed as mean \pm SD. Statistical analysis was done by unpaired student's ' $t$ ' test and chi-square test.

\section{Results}

Thirty six(36) male and 14 female IHD patients and 34 male and 16 female healthy subjects participated in this study. The anthropometric parameter of the subjects are shown in Table I. Although the mean serum $\mathrm{FT}_{3}, \mathrm{FT}_{4}$ and TSH level of both healthy subjects and IHD patients were within normal reference value but mean serum $\mathrm{FT}_{3}$, and $\mathrm{FT}_{4}$ level were significantly lower and serum TSH level was significantly higher in group B than that of group A (Table II). In respect to normal reference value both serum $\mathrm{FT}_{4}$ and FT3 below normal in 2 (4\%) subjects and TSH was higher in $4(8 \%)$ healthy subjects. Both low serum $\mathrm{FT}_{4}$ and $\mathrm{FT} 3$ were found in $3(6 \%)$ subjects and high TSH was found in 13 (26\%) subjects with IHD. The frequency of hypothyroids between two groups was statistically significant $(\mathrm{p}<0.05)$ (Table III).

Table I: Mean \pm SD age, body weight and BMI in two groups $(\mathrm{n}=100)$

\begin{tabular}{lccc}
\hline Parameters & Group-A $(\mathrm{n}=50)$ & Group- $\mathrm{B}(\mathrm{n}=50)$ & P values \\
\hline Age (years) & $57.30 \pm 11.53$ & $54.66 \pm 13.06$ & $0.287^{\mathrm{ns}}$ \\
BMI $\left(\mathrm{kg} / \mathrm{m}^{2}\right.$ & $22.18 \pm 4.73$ & $21.93 \pm 3.32$ & $0.759^{\text {ns }}$ \\
\hline
\end{tabular}

Group-A = Apparently healthy subjects (control group) Group-B = patients with IHD (study group) $\mathrm{BMI}=$ Body mass index ns $=$ non significant $(\mathrm{p}>0.05)$ 
Study of Thyroid Hormone Status in Ischemic Heart Disease

Article

Table II: Mean \pm SD serum $\mathrm{FT}_{3}, \mathrm{FT}_{4}$ and $\mathrm{TSH}$ in two groups $(\mathrm{n}=100)$

\begin{tabular}{lccc}
\hline Parameters & Group-A $(\mathrm{n}=50)$ & Group-B $(\mathrm{n}=50)$ & P values \\
\hline Serum $\mathrm{FT}_{3}(\mathrm{pmol} / \mathrm{L})$ & $4.56 \pm 1.56$ & $3.82 \pm 1.35$ & $0.012^{*}$ \\
Serum $\mathrm{FT}_{4}(\mathrm{pmol} / \mathrm{L})$ & $18.94 \pm 4.22$ & $15.94 \pm 4.39$ & $0.001^{*}$ \\
Serum TSH $(\mathrm{mIU} / \mathrm{L})$ & $2.65 \pm 1.99$ & $7.89 \pm 12.59$ & $0.004 *$ \\
\hline
\end{tabular}

Group-A= Apparently healthy subjects (control group) Group-B = patients with IHD (study group) * $=\mathrm{p}<0.05 * *=\mathrm{p}<0.01$

Table III: Distribution of hypothyroids in different groups

\begin{tabular}{lccc}
\hline Group & Group A & Group B & P value \\
\hline Serum FT $_{3}(\mathrm{pmol} / \mathrm{L})$ & $2(4 \%)$ & $3(6 \%)$ & \\
Serum $_{\mathrm{FT}}(\mathrm{pmol} / \mathrm{L})$ & $2(4 \%)$ & $3(6 \%)$ & $0.023^{*}$ \\
Serum TSH$(\mathrm{mIU} / \mathrm{L})$ & $4(8 \%)$ & $13(26 \%)$ & \\
\hline
\end{tabular}

Group-A = Apparently healthy subjects (control group) Group-B = patients with IHD (study group) $*=p<0.05$

\section{Discussion}

In the present study significantly lower serum $\mathrm{FT}_{3}$ and $\mathrm{FT}_{4}$ level and higher serum TSH level were found in IHD patients. Again, higher frequency of hypothyroids was found in $26 \%$ IHD of patients compared to that of $8 \%$ in healthy subjects. Several studies agree with the present findings. , $^{6,15,20-24}$

Auer et al. reported higher preva-lence of IHD in the patients with low serum $\mathrm{FT}_{3}$ level high serum TSH. ${ }^{6}$, Patients with hypothyroidism are more likely to develop IHD because of lipid metabolic derangement including dyslipidaemia and lipid peroxidation. ${ }^{6,8,15,20-27}$ Moreover, overt and subclinical hypothyroidism may result in accelerated atherosclerosis and IHD because of the associated hypertension, hypercholesterolemia and hyperhomocysteinaemia. Other suggested that reversible coronary dysfunction in the hypothyroidism causes impaired myocardial perfusion leading to IHD. $6,9,10,12,17$
In the cardiovascular system, thyroid hormone (TH) increases the number of â adrenergic receptors, increase the sensitivity of â adrenergic receptors to catecholamine- thus causes positive inotropic and chronotropic effects.It also increases the level of myosin in the heart as well as increase the strength of the heart. ${ }^{16}$

It has been suggested that hypothyroidism has been generally considered as an important cardiovascular risk factor in majority of studies. ${ }^{5}$ The dyslipidaemia associated with hypothyroidism is reported risk factors for the development of the atherosclerosis.9,12,22,24 Striking evidence of a higher prevalence of atherosclerotic cardiovascular disease in hypothyroid patients emerged from a large crosssectional study. The underlying mechanism that may be involved in the association between hypothyroidism and cardiovascular disease may include elevated serum total and LDLcholesterol, increased level of oxidized LDL in hypothyroids.

In contrast, Cappola et $\mathrm{al}^{18}$ reported that subclinical hypothyroidism is associated with atrial fibrillation but not with other cardiovascular disorder. Rodondi et al. ${ }^{22}$ stated that subclinical hypothyroidism is associated with an increased risk of congestive heart failure but not with other cardiovascular events or mortality. In the present study the higher percentage of hypothyroids in IHD patients than normal healthy subjects supports the notion that hypothyroid may be a co morbidity to IHD. 


\section{Conclusion}

The features of this study conclude that hypothyroidism may be associated with IHD. So, thyroid hormone levels should be observed in all middle aged population for early diagnosis of cardiac involvement. This may be helpful for better management of the IHD patients.

\section{Acknowledgement}

The authors of this article are thankful to the Cardiology Department of Dhaka Medical College Hospital, Dhaka for their co-operation.

\section{Author affiliations}

*1. Nasreen Sultana Lovely, Assistant Prof. of Physiology, AD-DIN Womens Medical College, Dhaka. Dom Inno 'Altura',Flat no-B5, 342, Segun Bagicha, Dhaka-1000

2. Rokeya Begum, Professor of Physiology,Dhaka Medical College, Dhaka.

3. Qazi Shamima Akhter, Associate Professor, Department of Physiology Dhaka Medical College, Dhaka.

4. Most. Sabinus Sultana, Assistant Prof of Physiology, IBN-SINA Medical College, Dhaka.

5. Salina Akhtar, Assistant Prof. of Physiology, SAPUR Dental Medical College, Dhaka.

* For correspondence

\section{References}

1. Bloomfield P, Bradbury A, Grubb NR, Newby DE. Cardiovascular disease. In: Boon NA College NR, Walker BR and Hunter JAA (eds). Davidson's principle and practice of medicine. Philadelphia: Elsevier ltd; 2006.pp519-646.

2. Scholen OFJ. The Heart. In: Kumar V, Abbas AK and Fausto N (eds). Robins and Cotran pathological basis of disease. India: Indian reprint ISBN; 2004.pp555-618.

3. Obuobie K, Smith J, Evans LM, John R, Davies JS and Lazarus JH. Increased Central Arterial Stiffness in Hypothyroidism. J clin Endocrinol Metab 2002;87: 4662-66.

4. Biondi B and Klein I. Hypothyroidism As A Risk Factor For Cardiovascular Disease. Endocrine 2004;24:1-13.

5. Mayer (Jr) O, Simon J, Filipovsky J, Plaskova M and Pikner R. Hypothyroidism In Coronary Heart Disease and Its Relation To Selected Risk Factors.
Vascular Health and Risk Management 2006; 2(4):499-506

6. Auer J, Berent R, Weber T, Lassnigh R, Eber B. Thyroid Function Is Associated With Presence And Severity Of Coronary Atherosclerosis. Clin cardol 2003;26:563-573.

7. Mariotti S and Cambuli VM. Cardiovascular Risk In Elderly Hypothyroid Patients. Thyroid vol.2007;17:1067-1073.

8. Fazio S, Palmieri EA, Lombardi G and Biondi B. Effects Of Thyroid Hormone On The Cardiovascular System 2004.31-50. Available at: rphr.endojournals.org. Access on 06/01/2010.

9. Biondi B, Palmieri EA, Lombardi G, and Fazio S. Effects Of Subclinical Thyroid Dysfunction On The Heart. Ann Intern Med 2002;137:904-914.

10. Hak AE, Pols HAP, Visser TJ, Drexhage HA, Holman A and Witteman JCM. Subclinical Hypothyroid Is An Independent Risk Factor For Atherosclerosis And Myocardial Infarction In Elderly Women; The Rottendam Study. Ann Intern Med 2000;132:270-78.

11. Rodondi N, Aujesky D, Vittinghof E, Cornuz J, Bauer DC. Subclinical Hypothyroidism And The Risk Of Heart Disease: A Meta-Analysis. Am J Med 2006;19:541-51.

12. Singh S, Duggal J, Molnar J, Maldonado F. Impact Of Subclinical Thyroid Disorders On Coronary Heart Disease; Cardiovascular And All-Cause Mortality: A Meta-Analysis. Int J Cardiol 2008;125:41-48.

13. Yun KH, Jeong MH, Oh SK, Lee EM, Lee J, Rhee SJ. Relationship Of Thyroid Stimulating Hormone With Coronary Atherosclerosis In Angina Patients. Int J Cardiol 2007;122:56-60.

14. Kahaly G.J. 2002. Cardiovascular And Atherogenic Aspects Of Subclinical Hypothyroidism. Thyroid 2001;10(8):665-79.

15. Miura S, IItaka M, Suzuki S, Fukasawa N, Kitahama S, Kawakami Y. Decrease In Serum Levels Of Thyroid Hormone In Patients With Coronary Heart Disease. Endo J 1996;43(6):657-63.

16. Barrett KE, Barman SM, Boitano S and Brooks HL. Ganong's Review of Medical Physiology. $23^{\text {rd }}$ ed. New Delhi: Tata McGraw Hill Education Private Limited; 2010. pp301-14.

17. Ladenson PW. Cardiovascular Consequences Of Subclinical Thyroid Dysfunction: More Smoke But No Fire. Ann Intern Med 2008;148:880-81.

J Bangladesh Soc Physiol. 2011 June; 6(1): 27-31 
18. Cappola AR, Fried LP, Arnold AM, Danese MD, Kuller LH, Burker GL et al. Thyroid Status, Cardiovascular Risk And Mortality In Older Adults. JAMA 2006;.295(9):1033-1041.

19. Mariotti S. Mild Hypothyroidism And Ischemic Hart Disease; Is Age The Answer? J clin Endocrinol Metab 2008;93(8):2969-71.

20. Pavlou HN, Kliridis PA, Panagiotopoulos AA, Goritsas CP, Vassilakos PJ. Euthyroid Sick Syndrome In Acute Ischemic Syndromes. Angiology 2002; 53:.699-707.

21. Iltumur K, Olmez G. Anturk Z, Taskesem T, Toprak N. Clinical Investigation; Thyroid Function Test Abnormalities In Cardiac Arrest Associated With Acute Coronary Syndrome. Clinical care 2005;9:416-24.
22. Rodondi N, Newman AB, vittinghof E, de Rekenneire N, Satterfield S, Harries TB, and Bauer DC. Subclinical Hypothyroidism And The Risk Of Heart Failure, Other Cardiovascular Events, And Death. Arch Intern Med 2005;165: 2460-2466.

23. Asvold BO, Bijero T, Nilsen TIL, Gunnel D and Vtten LJ . Thyrotropin Levels And Risk Of Fatal Coronary Heart Disease. The HUNT Study', Arch Intern Med 2008; 168(8): 855- 60.

24. Nanda N, Bobby Z, and Hamide A. 2008. Association Of Thyroid Stimulating Hormone And Coronary Lipid Risk Factors With Lipid Peroxidation In Hypothyroidism. Clin Chem Lab Med 2008; 46: 674-9. 